\title{
Strategi KBIH At-Taqwa dalam Meningkatkan Pelayanan Terhadap Calon Jamaah Haji
}

\author{
Heni Suhaini*, Ahmad Sarbini, \& Asep Iwan Setiawan \\ Jurusan Manajemen Dakwah, Fakultas Dakwah dan Komunikasi, \\ UIN Sunan Gunung Djati, Bandung \\ *Email : henisubainirahman@gmail.com
}

\begin{abstract}
ABSTRAK
Peneliti ini bertujuan sebagai proses penerapan untuk menyusun suatu rencana,mengimplementasikan program-program, dan menkoordinasikan aktivitas-aktivitas pelayanan demi berjalannya suatu tujuan agar tercapai dengan baik dalam suatu pelayanan. Pertanyaan peneliti untuk mengetahui perencanaan KBIH At-Taqwa dalam meningkatkan pelayanan terhadap calon jamaah haji. untuk mengetahui pelaksanaan program yang di berikan KBIH At-Taqwa terhadap calon jamaah haji. untuk mengetahui hasil program KBIH At-Taqwa dalam meningkatkan pelayanan terhadap calon jamaah haji. Metode yang digunakan dalam peneliti ini adalah metode desdkriptif dengan pendekatan kualitatif adapun. Teknik pengumpulan data yaitu observasi: wawancara, dan dokumentasi. KBIH At-Taqwa dalam meningkatkan pelayanan terhadap calon jamaah haji Pelayanan ketika pendaftaran sampai mendapat tahun pemberangkatan, Pelayanan proses pelaksanaan ibadah haji dan umrah, Pelayanan pasca haji/kafillah (ikatan alumni). Pelaksanaan program yang sudah ditetapkan oleh KBIH At-Taqwa sesuai kebutuhan dan dengan adanya programyang telah diberikan terhadap calon jamaah haji terutama bagi yang melaksanakan pertama kali. Hasil program KBIH dalam pelaksanaan program KBIH At-Taqwa terutama dalam pembimbingan terhadap calon jamaah haji dan keluhan-keluahan kepada KBIH At-Taqwa, maka akan menghasilkan KBIH yang lebih baik lagi. Keberhasilan Kelompok Bimbingan Ibadah Haji (KBIH) At-Taqwa dapat dilihat dari aspek kepuasan jamaah haji yaitu dari segi kualitas pelayanan KBIH AtTaqwa.
\end{abstract}

Kata Kunci: Strategi, KBIH, Pelayanan

\section{ABSTRACT}

The researcher aims as an implementation process to develop a plan, implement programs, and coordinate service activities for the purpose of running a goal to achieve well in a service. The researcher's question is to know the planning of KBIH At-Taqwa in improving the service for candidates of Haij pilgrimage, to know the implementation of the program provided by $\mathrm{KBIH}$ At-Taqwa for candidates of Haij pilgrimage, to find out the results of KBIH At-Taqwa program in improving services for the candidates of Haij pilgrimage. The method used in this 
research is descriptive method with qualitative approach. Then, data collection techniques are observation: interview, and documentation. KBIH At-Taqwa in improving service for the candidates of Hajj pilgrimage when registering until getting schedule of departure, Service process of Hajj and Umrah implementation, Post-Haij Service / Kafillah (Alumni Association). Implementation of programs that have been determined by KBIH At-Taqwa as needed and with the program that has been given for the candidates of Hajj pilgrimage especially of them who do it for the first time. The result of KBIH program in the implementation of KBIH At-Taqwa program especially in guidance to hajj pilgrims and complaints to KBIH At-Taqwa, will produce better KBIH. The success of the Hajj Guidance Group (KBIH) At-Taqwa can be seen from the aspect of the Haij pilgrims satisfaction in terms of quality service KBIH At-Taqwa.

Keywords: Strategy, KBIH, Service

\section{PENDAHULUAN}

Menunaikan ibadah haji diwajibkan atas setiap muslim yang mampu mengerjakannya secara materi, fisik, hutang-piutang, untuk melaksanakan seumur hidup sekali. Dengan cara mengunjungi tanah suci dan melakukan segala amalanamalan yang telah diatur dan ditetapkan, serta tata cara berdasarkan ajaran Rosulullah SAW. Ibadah haji hanya bisa dilakukan di bulan dzulhijjah, yaitu tanggal 9 sampai 13 dzulhijjah. Itu artinya, ibadah haji hanya bisa dilakukan sekali dalam satu tahun.

Haji pada hakekatnya merupakan aktifitas suci yang diwajibkan oleh Allah kepada seluruh ummat islam yang telah mencapai (istitho'ah) mampu, disebut aktifitas suci karena seluruh rangkaian kegiatan adalah ibadah. Haji juga disebut sebagai ibadah puncak yang melambangkan ketaatan serta penyerahan diri secara total kepada Allah baik secara fisik-mental maupun spiritual.

Haji merupakan salah satu ibadah yang diwajibkan atas setiap muslim yang mana mampu menjalanannya, kewajiban ini merupakan rukun islam yang kelima. kerena haji merupakan kewajiban, maka setiap orang yang mampu apabila dilakukan dia mendapat pahala ini berarti bahwa seorang telah melakukan haji yang pertama, maka selesai kewajibannya. Haji yang berikutnya, kedua, ketiga, dan seterusnya, merupakan ibadah sunnah. Allah SWT berfirman dalam surat Ali Imran Ayat 97:

[216]Barangsiapa memasukinya (Baitullah itu) menjadi amanlah dia; mengerjakan haji adalah kewajiban manusia terhadap Allah, Yaitu (bagi) orang yang sanggup Mengadakan perjalanan ke Baitullah. Barangsiapa mengingkari (kewajiban haji), Maka Sesungguhnya Allah Maha Kaya (tidak memerlukan sesuatu) dari semesta alam (QS : Ali Imran : 97) (Umar, 2010: 2).

Sedangkan menurut (Mansur, 1997: 2) mengatakan yang dimaksud dengan "sanggup mengadakan perjalanan ke Baitullah" dalam QS Ali Imran 97, yaitu: 1). Sehat jasmani dan rohani untuk menempuh perjalanan jauh dan melelahkan.2). Memiliki bekal yang cukup untuk membiayai darinya guna membayar biaya pelaksanaan ibadah haji, dan bekal bagi keluar dan yang ditinggalkannya. 3). Situasi aman untuk menunaikan ibadah haji dan ibadah umrah (tidak asa peperangan yang 
H. . Suhaini, A. Sarbini, \& A. I. Setiawan

dapat menghambat berlangsungnya haji dan umrah). 4). Mengerti tata cara pelaksanaan ibadah haji (manasik haji dengan baik dan benar).

Menunaikan ibadah haji berarti menunaikan rukun islam untuk ziarah ke Baitullah dengan cara melaksanakan rukun dan kewajiban yang telah ditentukan, antara lain: Ihram, Wukuf, Melontar Jumrah, dan Sa'i pada waktu yang telah ditentukan guna memenuhi panggilan Allah SWT dan mengharapkan RidhoNya (Departemen Agama RI, 1998:3).

Haji adalah rukun (tiang agama) islam yang kelima setelah syahadat, sholat, zakat, bagi umat islam dan puasa. Menunaikan ibadah haji adalah bentuk ritual tahunan yang dilaksanakan bagi umat islam seluruh dunia yang mampu secara material, fisik serta aman dari hutang piutang. Dengan berkunjung dan melaksanakannya beberapa kegiatan di beberapa tempat dalam satu waktu yang dikenal sebagai sebagai musim haji, hal ini berbeda dengan ibadah umrah yang bisa dilaksankannya sewaktu-waktu dalam menjalankan ibadah di tanah suci.

Ibadah haji merupakan perjalanan spiritul yang diperintahkan oleh Allah SWT. kewajiban tersebut ditunjukan bagi umat islam yang mampu secara materi, fisik dan mental. Di samping itu, dalam pelaksanaannya, jamaah haji harus memahami ilmu manasik haji. Dengan pemahaman tersebut diharapkan jamaah dapat menunaikan ibadah sesuai ketentuan syari'at Islam dan memperoleh haji mabrul. Bimbingan ibadah haji merupakan bagian dari pembinaan, pelayanan, dan perlindungan terhadap jamaah haji yang menjadi salah satu tugas pemerintah sebagimana dalam Undang-undang No 13 tahun 2008 (Tuntunan Manasik Haji dan Umroh, 2014: 1).

Dalam Undang-Undang Dasar Republik Indonesia No 2013 tahun 2008 tentang penyelenggaraan ibadah haji, pada bab satu (1) meliputi pelaksanaan, pembinaan, pelayanan, dan perlindungan calon jamaah haji. Yaitu tujuannnya memberikan pembinaan, pelayanan, dan perlindungan yang sebaik-baiknya bagi calon jamaah haji sehingga calon jamaah haji dapat menunaikan ibadahnya sesuai dengan ketentuan ajaran agama islam (Undang-Undang Dasar RI, 2008: 2). Pelaksanaan ibadah haji selalu sukses dan mencapai target yang di capai, maka perlu adanya suatu strategi, baik strategi dalam bidang pelayanan, penyuluhan dan bimbingan, manasik dan sebagainya. Sehingga apa yang menjadi cita-cita para calon jamaah dalam menunaikan ibadah haji ini bisa di peroleh secara sempurna.

Banyak KBIH-KBIH haji yang ikut mengurusi pelaksanaan ibadah haji, menimbulkan persaingan antara satu dengan yang lainnya, sehingga membuat para calon jamaah bingung mencari lembaga mana yang baik dalam memberikan pelayanan di segala bidang sehingga pelaksanaan ibadah haji bisa menghasilkan hasil yang memuaskan. Kegiatan ibadah haji mempunyai dua sisi yang harus diperhatikan dalam melaksanakannya, yaitu standar pelaksanaanya saat masih ditanah air dan mekkah. Pada standar pelayanan di tanah air banyak aspek penting yang harus diperhatikan pembinaanya seperti dalam pelayanan jasa (pembayaran setoran ONH ke Bank, pengurusan dokumen haji, pemeriksaan kesehatan bimbingan), penyediaan perlengkapan, dan konsultasi keagamaan. Sedangkan standar pembinaan ibadah haji di tanah suci adalah pelayanan akomodasi, 
transportasi, kesehatan, serta bimbingan haji (Ahmad Fauzi, Wawancara 4 April 2017).

Kelompok Bimbingan Ibadah Haji (KBIH) yang bergerak dalam penyelenggaraan haji sangatlah berperan yang mana tentang mengurus, mengelola, melaksanakan dan mengatur kegiatan-kegiatan yang telah direncanakan sebelumnya. Terutama dalam melayani para calon jamaah haji, pelayanan itu terbentuk untuk pegawai dalam mengefektifkan segiatan atau pelayanannya sesuai kondisi para calon jamaah haji, dalam keadaan apapun yang calon jamaah haji butuhkan terutama bagi calon jamaah yang pertama kali melaksanakan ibadah haji (Buku Pedoman KBIH, 2006: 1).

Strategi Kelompok Bimbingan Ibadah Haji At-Taqwa dalam salah satu lembaga yang bergerak di bidang jasa pelayana bagi orang yang ingin menunaikan ibadah haji seperti bimbingan, pelatihan dan pemberangkatan calon jamaah haji unruk membimbing dan mencoba membantu melancarkan pelaksanaan ibadah di indonesia kurang lebih dari segi pelayanan haji yang sudah di atur oleh undangundang tentang ibadah haji dan umroh sehingga berjalan dengan lancar. KBIH At-Taqwa merupakan prinsip kerja berdasarkan fungsi-fungsi strategi yang meliputi: perencanaan, pelasanaan, dan hasil.

Penulis menjadikan KBIH At-Taqwa sebagai obyek penelitian karena lembaga tersebut menerapkan strategi yang berorientasi pada peningkatan mutu pelayanan, dan untuk mengetahui bagaiamana KBIH At-Taqwa melayani calon jamaah dalam melaksanakan calon jamaah haji.

\section{LANDASAN TEORITIS}

Strategi adalah pendekatan secara keseluruhan yang berkaitan dengan pelaksaan, perencanaan dan didalam stategi terdapat tiga bagian. Salah satunya adalah strategi tradisional menekankan kepada kebebasan dalam berbagai keadaan (Rohmanur, 2010: 132).

Untuk memahami pengertian strategi, terlebih dahulu harus dapat dimengerti apakah strategi itu. Strategi berasal dari yunani, yaitu stratogos atau strategis yang mana jika diartikan jendral. Strategi berarti seni para jendral. Maka pengertian strategi dalam sudut militer adalah cara yang menempatkan pasukan atau menyusun kekuatan tentara di medan perang tujuannya agar musuh dapat dikalahkan (Saladin, 2003: 1).

Untuk memilih suatu strategik yang handal, maka para pegawai tersebut terlebih dahulu menganalisis kekuatan dan kelemahan perusahaannya. Djaslim (2003: 1-2) mengungkapkan mengenai konsep strategi diantaranya : a). Adanya suatu rencana tindakan yang dirancang untuk mencapai tujuan bukan hanya tujuan jangka pendek, akan tetapi juga jangka menengah dan jangka panjang. b). Untuk menyusun suatu strategi, diperlukan analisi terhadap lingkungan, baik lingkungan eksternal maupun internal, yaitu peluang dan ancaman atau tantangan maupun kekuatan dan kelemahan perusahaan. Hal ini penting untuk mengantisipasi perubahan yang terjadi. c). Strategi dirancang untuk menjamin agar tujuan dan 
sasaran dapat dicapai melalui langkah-langkah yang tepat (Saladin, 2003: 1-2).

Sebuah rencana uang disatukan, luas dan terintegrasi, yang menghubungkan keunggulan strategi perusahaan dengan tantangan lingkungan dan yang dirancang untuk memastikan bahwa tujuan utama perusahaan dapat dicapai melalui pelaksanaan yang tepat oleh organisasin (William dalam Saladin, 2010: 1).

Dari pengertian tersebut, disimpulkan bahwa strategi perusahaan adalah suatu kesatuan, rencana yang menyeluruh, komprehensif, dan terpadu yang diarahkan untuk mencapai tujuan perusahaan. Ada beberapa dari pengertian strategi di atas, yaitu: a). Adanya suatu rencana tindakan yang direncanakan untuk mencapai tujuan jangka menengah dan jangka panjang. b). Untuk menyusun suatu strategi, yang mana diperlukan analisis terhadap lingkungan, baik lingkungan ekstrernal maupun internal, yaitu peluang dan ancaman atau tantangan maupun kekuatan dan kelemahan perusahaan tersebut. Hal ini sangat penting untuk mengantisipasi perusahaan-perusahaan yang mengalami. c). Perlunya suatu keputusan pilihan dan pelaksanaan yang dapat dan terarah guna dalam mencapai sebuah tujuan perusahaan. d). Strategi dirancang untuk menjamin agar tujuan dan sasaran dapat.

Dess Gregory G dan Miller Alex, dalam buku (Djaslim Saladin, 2011: 1-3) ada dua bentuk strategi, yaitu yang pertama strategi yang dikehendaki dan yang kedua strategi yang direalisasikan. Strategi yang dikehendaki (intended strategic) : terdiri dari 3 (tiga) elemen, yaitu sasaran-sasaran (goals), kebijakan (policies), dan rencana-rencana (plans). Yaitu : 1). Sasaran-sasaran (goals) yaitu : apa yang ingin dicapai dalam sebuah organisasi atau perusahaan, sasaran itu mempunyai arti yang luas dan sempit.

Contoh : setiap orang secara pribadi ingin mencapai sebuah kebahagiaan dan hidupnya, inilah yang merupakan suatu sasaran yang luas. Dan untuk mencapai kegiatan itu diperlukan waktu, energi, dan sumber daya lainnya, inilah yang dimaksud dengan sasaran dalam arti yang sempit. Selanjutnya Gregory G Dess, dalam membagi hirarki atau tingkatan dari sasaran tersebut menjadi : a). Visi (vission) : apa yang akan dilakukan sebuah organisasi atau sebuah perusahaan visi merupakan karangka acuan dan presfektif sebagai satu keatuan yang mencerminkan dalam kegiatan nyata yang akan terjadi. b). Misi (mission) : banyaknya batasan-batasan sasaran yang akan dicapai. Misi adalah merupakan tugas dan prinsip pokok dalam mewujudkan visi. c). Tujuan-tujuan (objektives) : tujuan yang lebih spesifik yang ingin dicapai, secara ideal berarti kita harus mencari suatu kepastian akhir. d). Kebijakan (policies) : merupakan garis pedoman untuk bertindak, bagaimana sebuah organisasi mencapai sasaran-sasaran tersebut. e). Rencana-rencana (plans) suatu penyataan dari tindakan seseorang manajer oraganisasi terhadap apa yang telah diharapkan akan terjadi.

Ketika membicarakan sebuah strategi, wujud strategi adalah merupakan sebuah aitem atau yang lebih familiar dikenal sebagai komponen adalah unsur utama terciptanya sebuah wujud strategi. Dan untuk mengenal sebuah wujud strategi, maka penting adanya ciri khas. Adapun ciri-ciri strategi menurut (James AF Stoner, 1996: 140) adalah: 1). Wawasan waktu, meliputi cakrawala waktu yang 
jauh kedepannya, yaitu waktu yang diperlukan untuk melaksanakan sebuah kegiatan tersebut dan waktu yang diperlukan untuk mengamati sebuah dampaknya. 2). Dampak, walaupun hasil akhirnya dengan mengikuti strategi tertentu tidak langsung terlihat untuk jangka waktu yang singkat, namun dampak akhir akan sangat berarti. 3). Pemutusan upaya, sebuah strategi yang efektif biasnya mengharuskna pemutusan dalam kegiatan terhadap sasaran terutama sasaran yang sempit. 4). Pola keputusan, kebanyakan strategi mensyaratkan bahwa sederetan keputusan tersebut harus menunjang, artinya mengikuti suatu pola yang konsisten. 5). Peresapan, sebuah strategi mencakup suatu kegiatan operasi harian. Selain itu adanya konsistensi sepanjang waktu dalam sebuah kegiatan-kegiatan ini yang mengharuskan semua tingkatan organisasi bertindak secara naluri dengan caracara yang akan memperkuat strategi.

Oleh karena itu strategi dapat diartikan sebagai suatu pendekatan, barisan, atau kaidah-kaidah untuk mencapai sebuah tujuan dengan menggunakan tenaga, waktu, serta biaya yang dibutuhkan (hamdani, 2011: 18). Strategi merupakan bagian akhir dari bentuk pertama pelayana pada pelanggan, misi, nilai, serta tujuan dan strategi. Untuk mengubah strategi visi dan nilai-nilai menjadi kenyataan, pada saat tujuan pelayanan dan pelangan. Strategi adalah suatu seni dan ilmu dari pembuatan (Formulating), penerapan (Implementing) dan evaluasi (evaluating) dari keputusan-keputusan strategi antar dungsi-fungsi yang memunkinkan sebuah organisasi mencapai tujuan-tujuan dimasa yang akan datang (Wahyuni, 1996: 15).

Strategi perusahaan adalah pola keputusan dalam perusahaan yang menentukan dan mengungkapkan sasaran, maksud, atau tujuan, yang manghasilkan kebijaksaan utama dan merencanakan untuk mencapaian tujuantujuan ini, serta memperinci jangkauan bisnis yang akan dikejar oleh perusahaan, merupakan jenis organisasi ekonomi dan kemanusiaan yang diinginkan atau diharapkan, dan sifat dari penyaluran ekonomis yang diinginkan atau diharapkan, dan sifat dari penyeluran ekonomi dan non-ekonomis yang mana akan diberikan kepada pemegang saham, karyawan, pelunggan, dan masyarakat. Dalam organisasi berukuran atau berkeanekaan apapun strategi peusahaan itu biasanya berlaku bagi keluruh perusahaan, sedangkan strategi bisnis, kurang menyeluruh menegaskan pilihan produk atau jasa dan pasar bisnis tersendiri di dalam perusahaan. Strategi bisnis, yaitu penentuan tentang bagimana perusaan akan bersaing dalam bisnis tertentu dan menempatkan dirinya di antara saingannya. Strategi peusahaan ini menetukan bisnis yang akan dimasuki perusahaan untuk bersaing, kalau dapat cara memusatkan sumber-sumber untuk mengubah kemampuan yang nyata menjadi keuntungan bersaing. Keduanya adalah hasil proses berkesinambungan manajemen strategi, yang akan kita analisi secara terperinci.

Keputusan strategi yang menyumbang pada pola ini adalah yang efektif selama jangka waktu yang lama, memperngaruhi perusahaan dengan banyak cara yang berbeda dan memusatkan serta menyerahkan bagian yang berarti dari sumber-sumbernya kepada hasil yang diharapkan. serta posisi akan didudukinya dalam indrusti pemasarannya (Tamami, 1980: 19-20). 


\section{HASIL DAN PEMBAHASAN}

Latar belakang berdirinya KBIH At-Taqwa ini tidak terlepas dari sejarah Yayansan At-Taqwa, yang mana pada waktu itu di Wilayan Babelan Bekasi banyak masyarakat yang awam masalah ibadah haji. Sedangkan jamaah haji itu sangat sulit untuk daftar haji, kerna banyak hal-hal yang berat salah satunya dalam materi maka dari itu ibadah haji sangatlah berharga terutama dalam lingkungan masyarakat Ujung Harapan Kab. Bekasi.

Dalam melaksanakan kegiatan ibadah haji maupun umrah, KBIH At-Taqwa mempunyai produk-produk dalam perjalanan ibadah haji dan umrah yang telah ditawarkan. Hal ini dikemukankan oleh salahsatu staff KBIH At-Taqwa yaitu Fauzi (Wawancara, 5 Agustus 2017) selaku seketaris KBIH At-Taqwa yang menyatakan bahwa :

"Kelompok Bimbingan Ibadah Haji (KBIH) At-Taqwa memberikan bimbingan kepada calon jamaah haji dengan cara melayani sepenuh hati, memerikan kebutuhan ditanah air, di tanah suci, dan sampai kembali lagi di tanah air. Memberikan bimbingan manasik haji dengan para tokoh-tokoh agama yang mahir dan berpengalaman agar pelaksnaan ibadah haji bisa berjalan dengan tertib, lancar, dan memuaskan. Selain itu KBIH At-Taqwa memberikan dana talangan bagi masyarakat yang ingin menggunakan jasa KBIH ini". (Hasil wawancara bersama Fauzi di laksanakan pada 5 Agustus 2017).

Untuk menjalankan ibadah haji, kelompok bimbingan ibadah haji (KBIH) At-Taqwa membertika pelayanan jasa yang ditawarkan sebagai berikut : 1). KBIH At-Taqwa yaiu Pelayanan pendaftaran dan kepastian keberangkatan untuk menunaikan ibadah haji, Pemateri yang kompeten dan berpengalaman, Manasik, Multimedia, Alat peraga praktek manasik, Gedung manasik yang luas dan nyama, Konsumsi selama manasik, Obat-obatan yang telah disediakan. 2). Fasilitas yaitu : Tiket pesawat pulang pergi, Hotel dan Akomodasi sesuai peket, makan 3 kali sehari prasmanan menu Indonesia, Visa Umroh dan Ziarah di 2 tempat suci, Pembimbing mulai keberangkatan sampai kepulangan, Transportasi Bus Full AC di Negara tujuan, Menyediakan Muthowif wanita untuk ke Raudah, Manasik (Teori dan Praktik). 3). Akomodasi yaitu: Mekkah, Madinah, Pesawat, Pembuatan Paspor atau penembahan Nama dalam Paspor (kurang dari tiga kata), dan pembuatan surat Mahram, Pemeriksaan kesehatan, vaksin, Transportasi, Akomodasi, dan Konsumsi di luar program, Pengerluaran pribadi (telepon, laundry, bagasi, dll), Perawatan jika sakit atau meninggal, Biaya dorong dan sewa kursi roda, ketika Thawaf dan Sa'i bagi yang tidak kuat, Tip untuk Muthowif.

Dalam meberikan produk-produk yang ditawarkan kelompok bimbingan ibadah haji $(\mathrm{KBIH})$ At-Taqwa bertujuan untuk memerikan yang terbaik untuk calon jamaah haji yang menggunakan $(\mathrm{KBIH})$ At-Taqwa ini, dengan cara memberi pelayanan sepenuhnya maka para jamaah juga akan menawarkan sanak keluarganya untuk menggunakan jasa (KBIH) At-Taqwa. 


\section{Strategi Pelayana dan Analisis SWOT pada KBIH At-Taqwa}

Untuk memilih suatu strategik yang handal, maka para pegawai tersebut terlebih dahulu menganalisis kekuatan dan kelemahan perusahaannya. mengungkapkan mengenai konsep strategi diantaranya : 1). Adanya suatu rencana tindakan yang dirancang untuk mencapai tujuan bukan hanya tujuan jangka pendek, akan tetapi juga jangka menengah dan jangka panjang. 2). Untuk menyusun suatu strategi, diperlukan analisi terhadap lingkungan, baik lingkungan eksternal maupun internal, yaitu peluang dan ancaman atau tantangan maupun kekuatan dan kelemahan perusahaan. Hal ini penting untuk mengantisipasi perubahan yang terjadi. 3). Strategi dirancang untuk menjamin agar tujuan dan sasaran dapat dicapai melalui langkah-langkah yang tepat (Saladin, 2003: 1-2).

Strategi pelayanan di KBIH At-Taqwa yang terutama melayani calon jamaah haji secara maksimal, dan sah dalam pelaksanaan pelayanan hajinya. Maka dari itu KBIH memberikan ilmu-ilmu berkaiatan dengan ke hajian kita berikan kepada ja maah berupa bentuk manasik, yang mana KBIH At-taqwa memberikan 17 kali manasik dan di KBIH At-taqwa ketika memberikan manasik dengan metode ceramah, media audio fisual yang mana tujuannya untuk memudahkan jamaah membayangkan bagaimana haji itu teruma bagi yang belum mengerjakan haji. Seperti cara bagaimana proses haji, proses umrah, bagaiaman thawaf, dan bagaimana sa'i.

Selain bimbingan dari tanah air sudah dilayani, maka masih banyak pelayanan yang dilakukan seperti pembuatan paspor, proses priksa kesehatan, proses perbankan ketika jamaah itu setoran, pendaftaran ke depag dan lainnya sehingga sampai ketanah suci sehingga kembalagi ke tanah air.

Analisis strategi yang dimaksud adalah SWOT yang merupakan analisis lingkungan internal dan ekternal organisasi yang telah dikenal luas. Hasil dari analisis SWOT ini dapat menunjukkan kualitas dan kuantifikasi posisi organisasi tersebut dengan sejumlah kemampuan-kemapuan inti. Bila resultasi kekuatan dan kelemahan positif, yang kemudian memberikan rekomendasi strategi terhadap strategi serta rekomendari fungsional kebutuhan atau modifikasi sumber daya organisasi (Yusanto \& Kusuma, 2003: 29).

Dalam evaluasi program juga meningkatkan pelayana terhadap calon jamaah haji ini, maka diperlukan suatu analisis SWOT. Analisi SWOT merupakan karangka pilihan bagi banyak manajer selama priode waktu yang panjang karena kesaderhanaanya dan kemampuannya untuk menggambarkan esensi dari formulasi strategi yang baik. Menyesuaikan peluang dan ancaman suatu perusahaan dengan kekuatan dan kelemanahan.

Analis yang pertama adalah Streng (Kekuatan) Analisis kekuatan adalah dalam setiap perusahaan pada atau organisasi perlu meilai kekuatan-kekuatan dan kelemahan di bandingkan dengan para pesaingnya. Misalkan jika kekuatan perusahaan tersebut unggul di dalam teknologinya, maka keunggulan itu dapat di manfaatkan untuk mengisi segmen pasar yang membutuhkan tingkat teknologi dan juga kualitas yang lebih maju. 
Demikian kekuatan ini adalah keuntungan yang dimiliki, kekuatan startegi pelayanan KBIH At-Tqwa terhadap calon jamaah haji adalah dengan dasar hukum yang dimiliki oleh pemerintah tentang penyelenggaraan haji.

Analisis yang kedua adalah Weakness (kelemahan) Analisis kelemahan, dalam situasi ataupun kondisi yang merupakan kelemahan di dalam sebuah perusahaan ataupun organisasi yang menjadi kendala yang serius adalah dalam kemajuan suatu perusahaan atau organisasi. Menyambungkan dalam kelemahan strategi pelayanan KBIH At-Taqwa terhadap calon jamaah haji belum memanfaatkan kecanggihan teknologi seperti periklanan di televisi, internet.

Analisis yang ketiga adalah Opportunities (peluang) Analisis peluang, dalam situasi atau kondisi ini yang merupakan peluang diluar suatu perusahaan atau peluang dan memberikan peluang berkembangnya bagi perusahaan dimasa depan. Cara ini adalah untuk mencari peluang ataupun terobosan yang menungkinkan suatu perusahaan ataupun suatu organisasi berkembang di masa yang akan datang.

Peluang yang KBIH At-Taqwa meiliki yaitu berdiri dibawah naunguan yayasan yang sudah cukup ternakal dikelilingan masyarakat Bekasi-Jakarta. Jadi ketika dalam kesempatan acara besar seperti: 1) Maulid Nabi SAW dengan kehadiran ribuan masyarakat, disitulah KBIH At-Taqwa berkesematan untuk melakukan periklanan. 2) Radio, dengan memiliki chanel yayasan At-Taqwa KBIH At-Taqwa ini melakukan periklanan dan khususnya pada hari Rabu sore. 3) Pondok pestren, dalam adanya suatu pesantren yang pendirinya salah satu Pahlawan Nasional maka KBIH At-Taqwa selalu melakukan penawaran jasa kepada para guru-guru dari At-Taqwa pusat maupun cabang.

Analisis yang keempat adalah Threats (hambatan/ancaman)Analisis ancaman, dalam analisis ini bagaimana caranya menghadapi sebuah ancaman yang dihadapi oleh suatu perusahaan. Untuk menghadapi berbagai macam faktor lingkungan yang tidak menguntungkan pada suatu peursahaan yang menyebabkan kemunduran, jika ada segera diatasi karena ancaan tersebut bisa menjadi penghalang bagi suatu usaha yang bersangkutan baik di masa skrang maupun di masa yang akan datang.

Suatu ancaman terjadi adalah adanya keadaan yang tidak menguntungkan. Ancaman yang dihadapi pada strategi pelayanan KBIH At-Taqwa terhadap calon jamaah haji adalah: 1) Adanyan KBIH atau Travel-trevel haji yang menjanjikan kelebihan yang dimiliki dan ditawarkan dalam perjalanan haji, sehingga bagi kalangan yang mempunyai dana lebih, mereka lebih memilih KBIH atau Trevel haji yang menjanjikan dari KBIH At-Taqwa. 2) Banyaknya Kelompok Bimbingan Ibadah Haji (KBIH) atau Travel-trevel yang membantu calon jamaah haji bagi mereka yang tidak ingin repot.

Keberhasilan suatu strategi yang telah ditetapkan saat ditentukan oleh seberapa besar tingkatan kesulitas strategi tersebut dengan perubahan lingkungan, persaingan, serta situasi perusahaan. Analisis perencanaan strategi yang bersifat strategis, maka dengan kondisi atau informasi yang diperoleh dari suatu kasus, tindak an manajemen yang tepat dan sesuai dapat ditentukan. 


\section{Perencanaan KBIH At-Taqwa dalam Meningkatkan Pelayanan Terhadap Calon Jamaah Haji}

Strategi merupakan bagian akhir dari bentuk pertama pelayana pada pelanggan, misi, nilai, serta tujuan dan strategi. Untuk mengubah strategi visi dan nilai-nilai menjadi kenyataan, pada saat tujuan pelayanan dan pelangan. Strategi adalah suatu seni dan ilmu dari pembuatan (Formulating), penerapan (Implementing) dan evaluasi (evaluating) dari keputusan-keputusan strategi antar dungsi-fungsi yang memunkinkan sebuah organisasi mencapai tujuan-tujuan dimasa yang akan datang (Wahyuni, 1996: 15).

Kelompok Bimbingan Ibadah Haji (KBIH) merencanakan dalam meningkatkan pelayanan terhadap calon jamaah haji, maka KBIH At-taqwa memanfaatkan media untuk sosialisasi untuk meningkatkan minat jamaah seperti : a) Momen walmatu safari untuk meminta waktu mensosialosasikan jamaah lembaga KBIH At-Taqwa. b) Melalui Radio At-Taqwa mengiklanin dan jadwalnya rutin tentang haji pada setiap hari selasa sore, sehingga para pendengar yang lagi dalam perjalanan atau sebagainya bisa mendengarkan dan tergugah hatinya.

Dari memberika pelayanan yang maksimal kepada jamaah haji dan umrah, maka mereka juga merasa puas dengan pelayanan di KBIH At-Taqwa ini sehingga dari cerita-cerita para calon jamaah haji akan timbul daya tarik dan merakana kenyamaan untuk mendaftarkan diri kepada jasa KBIH At-Taqwa. Secara umum, pelayanan yang baik merupakan pelayanan cepat, ramah, jujur. Hal ini katakan oleh (Ahmad Fauzi. Wawancara, 5 Agustus 2017) yaitu:

"pelayanan yang diinginkan masyarakat, terutama masyarakat awam/belum pernah melakukan ibadah haji. mereka mebutuhkan pelayanan yang full dari suatu KBIH, dan kami sebagai Kelompok Bimbingan Ibadah Haji (KBIH) At-Taqwa berusaha melayani yang dibutukan masyarakat". (Hasil Wawancara bersama Ahmad Fauzi. Wawancara, 5 Agustus 2017).

KBIH At-taqwa menyambut dengan hangat dan melayani agar mereka nyaman. KBIH At-taqwa mempunyai keunggulan yang mana biasanya ketika mendaftarkan ke Bank dan berlama-lama mengantri, akan tetapi di KBIH Attaqwa ini beda kerna sudah bekerja sama dengan bagian Bank yang disekitar Kab Bekasi sehingga dari pihak Bank tersebutlah yang datang ke KBIH At-taqwa untuk membuat buku tabungan para calon jamaah haji yang menggunakan jasa KBIH At-taqwa.

Selain membuka buku tabungan ke Bank, maka tahap selanjutnya yaitu mendaftarkan ke Depak. Jarak antara depak dengan KBIH ini cukup jauh dan ketika calon jamaah haji tidak mempunya kendaraan maka dari pihak KBIH Attaqwa meberikan fasilitas seperti mobil dan para staff yang bersangkutan akan membimbing mendaftarkan kebagian depag kehingga calon jamaah tinggal duduk manis menerima hasil dan merasakan kenyamanan atas fasilitas peayanan yang KBIH At-taqwa berikan.

Adapun untuk pembayaran pendaftaran ketika pergi ibada haji yaitu 
H. . Suhaini, A. Sarbini, \& A. I. Setiawan

terperinci sebagai bertikut: 1) Membuka tabungan haji dengan jumlah sesuai ketentuan masing-masing Bank Syariah Penerima Setoran (BSPS) min. Rp. 25.500.000. 2) Meminta berkas validasi dari Bank Syarih Penerima Setoran (BSPS) dengan membawa pas foto Haji Ukuran $3 \times 4=5$ buah, $4 \times 6=5$ buah. 3) Pendaftaran pergi Haji dilakukan langsung oleh yang bersangkutan/tidak boleh diwakilkan, di Kantor KEMENAG Kota/Kabupaten setempat dengan syarat membewa: a) Berkas validasi dari Bank Syariah Penerima (BSPS). b) Fhotocopy buku Tabungan Haji dengan Nilai Rp. 25.000.000. c) Fhotocopy KTP 5 lembar (Format A4). d) Fhotocopy Kartu Keluarga 5 lembar (Format A4). C) Surat persyaratan dari Lurah diketahui Camat tentang kebenaran yang bersangkutan sebagai penduduk daerah setempat di atas materai 6000 (FC. 3 lembar). d) Surat keterangan dari kesehatan dari Puskesmas setempat (FC. A4 3 lembar). e) Pas foto khusus haji dengan ukuran panjang dari dagu sampai kening 70\%-80\% ukuran kepala, berwarna latar belakang putih tidak berkerudung putih, tidak berpeci, tidak berkaca mata, jumlah yang diperlukan: ukuran $3 \times 4=40$ buah, 4 × $6=20$ buah, f) Membawa fhotocopy Surat Nikah/Akta Lahir/Ijazah. g) Usia calon Haji minimal 12 tahun kecuali sudah menikah (Surat Nikah). h) Jamaah mendapatkan berkas No. Porsi langsung dari KEMENAG /SISKOHAT. i) Berkas Nomor Porsi tersebut langsung diregistrasi oleh KEMENAG sebagai bukti booking Haji. j) Menunggu waktu pelunasan Biaya Perjalanan Ibadah Haji (BPIH).

Adapun untuk persyaratan pergi umrah dan visa ke negara lain adalah sebagai berikut: 1) Paspor yang masih berlaku minimal 7 bulan. 2) Fhotocopy KTP (2 lembar). 3) Kartu vaksinasi maningitis. 4) Pas foto berwarna dengan latar belakang putih dan proporsi $80 \%$ wajah, ukuran: $3 \times 4$ (4 lembar) dan 4 x 6 (4 lembar). 5) Surat nikah dan kartu keluarga Asli bagi yang berangkat Suami-Istri. 6) Akte kelahiran Asli bagi Anak yang berangkat dengan orang tuanya. 7) Kartu keluarga Asli/Akte kelahiran asli bagi yang berangkat sendiri baik laki laki atau perempuan (usia dibawah 45 tahun). 8) DP sebesar \$1.000,-per orang. 9) Pelunasan biaya program paling lambat 2 (dua) minggu sebelum keberangkatan.

Adapun standar pelayanan pada Kelompok Bimbingan Ibadah Haji (KBIH) At-Taqwa untuk Pembimbing (tour leader) adalah sebagai berikut:

Yang pertama sebelum Keberangkatan: a) Satu Minggu sebelum keberangkatan, pembimbing (tour leader) ibadah diharuskan mengenal data jamaah melalui staff KBIH Salman dan Travel Safari Suci dan melakukan pengecekan berbagai persiapan keberangkatan baik menyangkut jamaah maupun pembimbing. b) Paling lambat dua atau satu pekan sebelum keberangkatan, pembimbing (tour leader) harus memberikan pengarahan/latihan manasik umroh kepada jamaah.

Yang kedua pada Saat Keberangkatan: a) Pada hari pertama, pembimbing (tour leader) sudah harus tiba di tempat pemberangkatan 1,5 jam sebelum jadwal keberangkatan. b) Setelah seluruh jamaah kumpul, pembimbing (tour leader) menyampaikan tausiah singkat dan memimpin doa. c) Sebelum tiba di airport, pembimbing (tour leader) segera menghubungi staff yang melaksanakan airport handling untuk segera melakukan chek in group di counter yang telah ditentukan. d) Di airport, pembimbing/tour leader harus membimbing jamaah agar dapat 
berkumpul di suatu tempat dan mengkondisikannya. e) Jika ada jamaah yang belum datang, maka pembimbing (tour leade) harus proaktif menghubungi jamaah tersebut. f) Pembimbing (tour leader) harus mengetahui dan mencatat jumlah koper atau luggage yang akan dimasukan ke bagasi pesawat. g) Setelah semua jamaah berkumpul dan semua urusan chek in telah selesai, pembimbing (tour leader) segera membagikan pasport, ticket, boarding pass, dan bukti telah bayar fiscal, luggage tag, dan embarkation card kepada masing-masing jamaah. h) Apabila sampai pada antrian pemeriksaan imigrasi, pembimbing (tour leader) harus mempersiapkan jamaah terlebih dahulu, dan berada pada antrian paling belakang. i) Pembimbing (tour leader) harus membawa jamaah menuju waiting lounge. j) Diusahakan agar pembimbing (tour leader) menjadi orang terakhir yang masuk pesawat.

Adapun pada saat didalam pesawat tugas pembimbing KBIH At-Taqwa bertugas sebagai berikut: a) Usahakan pembimbing (tour leader) mengetahui posisi tempat duduk jamaah. b)Pembimbing (tour leader) melakukan pengecekan ulang dan memastikan jumlah keseluruhan jamaah. c) Pembimbing (tour leader) harus membantu jamaah agar memperoleh tempat duduk yang berdekatan.

Adapun pada saat kedatangan ditempat tujuan tugas pembimbing adalah sebagai berikut: 1)Pada saat tiba di Negara tujuan pembimbing/tour leader segera menghubungi (via telp) local guide/muthawwif kita di Negara tujuan. 2)Pada saat tiba di Negara tujuan, pembimbing (tour leader) membimbing semua jamaah untuk menuju immigration counter Negara yang bersangkutan. 3)Pada saat berada di immigration counter pembimbing (tour leader) harus berada di barisan paling belakang, terutama untuk memastikan tidak ada jamaah yang tertinggal atau menghadapi masalah. 4)Setelah keluar dari immigration counter jamaah dibimbing menuju tempat pengambilan bagasi/conveyor. 5)Setelah memastikan tidak ada barang yang tertinggal pembimbing (tour leader) langsung memandu jamaah menuju pintu keluar airport dan bertemu dengan local guide/muthawwif. 6)Setelah keluar dari airport, jamaah dibawa menuju bis, pastikan kembali tidak ada barang yang tertinggal. 7)Di dalam bis pembimbing/muthawwif membimbing do'a dan menyampaikan pengumuman yang dianggap penting.

Dalam pembayaran Manasik di KBIH At-Taqwa dibagi menjadi tiga, yaitu biaya : 1) Biaya Bimbingan selama di Tanah Air.Biaya pemberangkatan pembimbing.Biaya manasik.Oprasional pemberangkatan dan pemulagan.Infaq untuk yayasan.Biaya oprasional KBIHSemua berjumlah Rp. 3.000.000,- 2) Biaya Handling ; Kain ihram. Mukena.Seragam KBIH. Slayer. Administrasi pemberkasan paspor. Administrasi buku manasik. Tambang dan gembok koper. Administrasi koper Semua berjumlah Rp. 1.300.000,- 3) Biaya selama di tanah suci Jasa muthowwif (Guide). Paket ziarah mekkah. Paket ziarah madinah. Paket ziarah jeddah. Paket umrah 5 kali (3 kali tan'iem, 1 kali hudaibiyah, 1 kali ji'ronah) Catering saat baru tiba di mekkah. Konsumsi ziara jeddah. Tasyakuran haji di mekkah. Baksis/Tips-tips. Semua berjumlah Rp. 300 Real (1.260.000,-).

\section{Program-Program Apa Saja yang diberikan KBIH At-Taqwa kepada Calon Jamaah Haji}


H. . Suhaini, A. Sarbini, \& A. I. Setiawan

Materi Manasik dalam bimbingan manasik Haji dan Umrah KBIH At-Taqwa Kec. Baleban Kab. Bekasi disampaikan oleh para ulama dan pembingmbing yang sudh berpengalaman yaitu :

Materi Dasar yang pertama Peraturan dan Undang-undang tentang Penyelenggaranaan Ibadah Haji. yang kedua Buku-buku panduan Perjalanan Ibadah Haji dan Departeman Agama RI. Yang ketiga Al-Quran dan Terjemahnya. Yang keempat Kitab. Yang kelima Perjalanan Ibadah Haji. yang ke enam Kesehatan Jamaah Haji. yang ketuju Perbekalan Jamaah Haji.

Materi inti yang pertama Syarat Rukun Ibadah Haji dan Umrah. Yang kedua Cara Berihram, Towaf, Sai, Tahalul, Wukuf, Melontar, Mabit. Yang ketiga Larangan-laranga n Ihram. Yang ke empat Cara Melaksanakan DAM dan Qurban. Yang kelima Cara Tayamum, cara Sholat di pesawat, cara Sholat Jama' Takdim dan Takhir secara Tam dan Qosr serta cara mendirikan Sholat Mayit. Yang keenam Cara-cara Berziarah. Yang ketuju Macam-macam Doa dalam Haji, Umrah dan Ziarah. Yang kedelapan Mewajibkan Calon Jamaah Haji untuk mengikuti Manasik Haji. yang ke sembilan Mewajibkan Calon Jmaah Haji untuk mengikuti Manasik Haji di tingkat Kabupaten Bekasi oleh Kemenag Kab Bekasi.

Materi lainnya yaitu ; Kesehatan. Perjalanan Haji.Praktik Lapangan. Keentuan-ketentuan di Pesawat. Ketentuan di Penginapan Mekkah dan Madinah. Dan yang terkahir Simulasi Wukuf.

Bimbingan Manasik dalam melaksanakan bimbingan manasik, KBIH Attaqwa memberikan pelayanan kepada para calon jamaah haji dengan pelayanan full agar masyarakat yang memakai jasa KBIH ini merasakan kepuasan. Kelompok Bimbingan Ibadah Haji (KBIH) ini mengatakan bahwa:

"untuk meningkatkan kepuasan pelanggan, kami meningkatkan bimbingan ibadah yang berkualitas. KBIH At-Taqwa memberikan para pemateri manasik para toko-tokoh/ulama agama agar pelaksanaan manasik dari segi ilmu, akhlak, dan pengalaman tidak diragukan lagi" ( Hasil Wawancara bersama fauzi dilaksanakan pada tanggal 05 Agustus 2017).

Bimbingan Manasik Ibadah Haji di Tanah Air sebanyak 17 kali pertemuan

Paket Ziarah : a) Makkah (Masy'aril Haram) dan sekitarnya antara lain. b) Maulid Nabi Muhammad Saw. c) Masjid Jin. d)Pemakaman e)Umum Ma'la. f) Arofah, Muzdalifah, Mina. g) Jabal Rahmah, Jabal Tsur, Jabal Nur. h) Peternakan Unta, Musium Ka’bah/ Al Haromain

Jeddah dan sekitarnya antara lain : Masjid Terapung. Masjid Qishos. Makam Siti Hawa. Panorama Air Mancur Laut Merah.Mall Qournish/ Suq Balad Madinah dan sekitarnya antara lain : Sekitar Wilayah Masjid Nabawi. Raudhoh, Makam Nabi Muhammad, SAW. Abu Bakkar, dan Umar bin Khattab. Pemakaman Umum Baqi. Masjid Ali Bin Abi Thilib, Abu Bakar, Umar bin Khattab, Ghomamah, Utsman, Bilal, Suq Tamar,dan Masjid Ijabah. Jabal Uhud, Masjid Qiblatain, Masjid Quba, Masjid Jum'at, Masjid Khandak, dan Pasar Kurma Nuzhah. Percetakan Al-Qur'an. Jabal Magnet. Muthowwif di Makkah. Qiyamullail, SertifikatHaji /BadalHaji \& Agenda Kenangan 
Tempat dan Waktu Manasik Haji .Tempat pelaksanaan bimbingan calon jamaah haji dilaksanakan disekitar KBIH At-Taqwa yaitu di lapangan Masjid AtTaqwa. Waktu penataran manasik haji ini dilaksanakan senyak 17 kali pertemuan pada jam 07.30 sd 11.30, dan dilanjutkan istirahat serta siap-siap untuk sholat dzuhur berjamaah. Bimbingan di Tanah Suci Bimbingan di Madinah AlMunawwaroh. Membimbing atau mengenalkan Masjid Nabawi. Membimbing sholat fardu sebanyak 40 x (Arba’in). Membimbing Ziarah ke Makam Rosulullah SAW dan Ke tempat-tempat bersejarah dan lainnya. Membimbing Sholat dan memasuki Raudloh. Mengelilingi kota Madinah (percetakan Al-Quran). Membimbing ke Madinah. Bimbingan di Mekkah Al-Mukarromah Membimbing pemakaian kain Ihram. Membimbingn niat Umrah di Miqot. Membimbing Talbiyah sepanjang jalan menuju Mekkah.

Membimbing Thoqwaf, Sa'i dan Tahallul Umroh mengenalkan Masjidi Harom dan Sekitarnya. Membimbing Ziarah ke tempat-tempat bersejarah. Mengelilingi kota mekkah Al-mukarromah (Jabal Tsur, arofah, Jabar Rohmah, Muzdalifah, Mina< Jamarot, Jabal Nur). Mebimbing Umrah Sunat dari Ji'ronah, Tan'iin dan Hudabiyah. Membimbing Sholat Fardu, Sholat Tahajjud dan I'tikaf di Masjidil Haram. Membimbing Ibadah Wukuf di Arafah, Mabit di Muzdalifah, mengambil krikil, melempar Jumroh, dan Mabit di Mina. Membimbing penyembelian DAM dan Qurban.

Membimbing syukuran atas selesainya prosesi pelaksanaan Ibdaha Haji di Mekkah Al-Muharromah. Bimbingan di Jeddah Membimbing Ziar ah ke Makam Siti Hawa. Membimbing mengelilingi Kota Jeddah dan Laut Merah. Membimbing Ziarah ke tempat-tempat Bersejarah.

\section{Bagaimana Hasil Program KBIH dalam Meningkatkan Pelayanan Terhadap Calon Jamaah Haji}

Kelompok Bimbingan Ibadah Haji (KBIH) At-Taqwa setiap tahunnya pasti melakukan evaluasi program, misalkan pada tahun 2016 para bimbingan berkumpul untuk melaksanakan evaliasi apa saja kesulitannya, apa saja kekurangannya, apa saja kendalanya disampaikan semuanya sehingga kemudia diperbaiki apa saja kekuarangannya sehingga untuk mebekalan pemberangkatan tahun yang akan datang. Ketika tiba saatnya pemberangkatan haji itu, maka sebelumnya para pembimbing berkumpul untuk mengevaluasi kekurangan di tahun lalu untuk dijadikan pembelakan agar menjadi lebih baik lagi.

Dalam mengevaliasi, maka diperlukan evaluasi yang efektif yaitu ada 3 (tiga) evaluasi yaitu : 1). Ekonomikal. Dalam hasil, aspek yang kita perlukan adalah sebuah informasi atas kinerja yang indikatornya sudah diterapkan terlebih dahulu. Bila informasinya lengkap maka akan semakin baik tentunya, tapi itu bukan berarti lantas informasi harus banyak. Terlalu banyak informasi bukan berartti lebih baik daripada terlalu sedikit informasi. Dalam suatu pengawasan kita juga memperhitungkan biaya-manfaatnya. Kalau kita mengontrol segala sesuatu (termasuk yang tidak penting), maka kemungkinan hal tersebut malah akan 
H. . Suhaini, A. Sarbini, \& A. I. Setiawan

mengganggu organisasi, karena setiap oarang akhirnya pekerjaannya hanya mengontrol. Pada prinsipnya, semakin banyak yang mengawasi, akan semakin besar biayanya. Maka dari itu, fokus dengan suatu yang di tuju saja dalam menjalankan aktivitas hasil. 2). Aspek dan bermakna. Karakter kedua ini masih berhubungan dengan karakter yang pertama. Tindakan hasil yang kita lakukan, harus sesuai dengan tujuan yang kita tetapkan sebelumnya. Karena itulah penentuan prioritas, kreteria dalam penilaian, pembobotan yang akurat menjadi penting dalam hasil kinerja. 3). Tepat waktu, hasil yang dilakukan selayaknya tepat waktunya. Karena itu suatu perusahaan dalam situasi persaingan bisnis sekarang harus memanfaatkan dukungan teknologi informasi. Berbagai persoalan yang terkait dengan kemutakhiran informasi untuk pengawasan kini bisa dipecahkan dengan dukungan teknologi.

Untuk sekedar menggambarkan karakter ini, maka ketika sedang melakukan hasil kita tidak perlu melakukan hal-hal yang tidak penting. Bikan hanya biaya saja yang merugi, akan tetapi maslah waktu dan hasil yang tidak maksimal nantinya. Hasil yang baik karena dilakukan oleh oarang-orang yang bersangkutan dan bertanggung jawab untuk satu tujuan yaitu menuju yang lebih baik untuk kedepannya.

Berdasarkan hasil penelitian yang dilakukan oleh penulis dapat dianalisis bahwa strategi KBIH dalam meningkatkan pelayanan yang diberikan terhadap calon jamaah haji baik dalam pendaftaran, bimbingan manasik, dan sampai pelaksanaan ibadah haji yaitu memberikan pelayanan dalam kenyamanan yang terbaik dan bijaksana. Sehingga pada setiap tahunnya mendapat peningkatan calon jamaah haji setiap tahunnya, bahkan untuk di tahun 20 .

Pelayanan yang diterapkan oleh KBIH At-Taaqwa ini menunjukan siap membantu kebutuhan para calon jamaah haji/umrah, dan memberikan pelayana yang teraik terhadap calon jamaah haji, kerna sesuai dengan apa yang menjadi Mottonya "bersama kami anda aman dan nyaman". Hal ini bukan hanya hasil dari wawancara dari para staff KBIH At-Taaqwa saja, akan tetapi dari hasil wawancara masyarakat sekitarnya terutama para calon jamaah haji/umrah dan jamaah haji/umrah yang menggunakan jasa KBIH At-Taaqwa mengatakan bahwa merasa sangat puas.

Untuk melakukan ini semua pastinya dibutuhkan strategi yang sesuia kebutuhan bidang pelayanan yang baik terhadap jamaah dan lembaga tersebut dengan ketentuan yang sudah ditentukan. Adapun menurut Fred R. Dafid bahwa strategi adalah mencapai suatu tujuan atau solusi untuk masalah (Bussinesdictionary) dan strategi sebagai rencana sebuah program atau langkah rencana (a directed course of action).

Selanjutnya adalah program-program strategi yang dilakukan oleh $\mathrm{KBIH}$ At-Taqwa dalam masalah pelayanan sebagai berikut: 1). Perencanaan pelayanan pada KBIH At-Taqwa. Dalam perencanaan haji adalah bagaimana cara untuk melayani secara maksimal dengan ramah, sopan, dan memuaskan sesuai dengan kebutuhan pelanggan. Hal ini sebagai gambaran agar strategi yang dilakukan dalam kegiatan saat ini, masa yang akan datang dan selanjutnya untuk penyelenggaraan 
ibadah haji. Untuk perencanaan pelayanan ibadah haji dan ibadah umrah di KBIH At-Taqwa sudah memiliki Standar Operasional Prosedur (SOP) yang telah ditetapkan oleh pemerintah. Demikian yang dikatakan oleh Fred R. Dafid di atas yaitu sebuah strategi bersama dengan tujuan jangka panjang hendak dicapai. Strategi mempengaruhi perkembangan jangka panjang perusahaan, biasanya untuk lima tahun ke depan, dan karenanya berorientasi ke masa yang akan datang. 2). Pelaksanaan pelayanan pada KBIH At-Taqwa, berdasarkan kasil penelitian bahwa pelaksaan di KBIH At-Taqwa telah sudah membagi-bagikan tugas kepada para staff sesuai dengan bidangnya, ada bagian pelayanan pendaftaran calon jamaah sampai mendaftarkan buka tabungan, ke kemenag, pembuatan visa. Bagian membimbing manasik di tanah air dan di tanah suci sampai pemungan jamaah ke tanah air, dan banyak tugas-tugas laninnya yang dibagikan sesuai dengan struktur KBIH At-Taqwa. 3). Hasil pelayanan pada KBIH At-Taqwa

Dari hasil peneltian bahwa pengawasan ketika pemberangkatan calon jamaah haji dan calon jmaah umrah, maka pihak KBIH At-Taqwa ikut serta mendampingi dari tanah air sampai tiba ke tanah suci bahkan kembali lagi ke tanah air para petugas KBIH At-Taqwa tidak lepas mengawasi dan melayani.

Dalam pelaksanaan pelayana KBIH At-Taqwa mengukur pelaksanaan sejauh mana pelaksanaan tersebut dalam mencapai tujuannya, dan apabila terdapat penyimpangan maka secara langsung melakukan perbaikan. Untuk mengetahui apa saja kekurangan dalam pelayanan yang telah diberikan oleh pihak KBIH AtTaqwa terhadap calon jamaah termasuk keluhan-keluhan yang dirasakan oleh jamaah serta saran maka para petugas mengadakan musyawarah atau hasil terkait dengan samalah yang ada.

Jadi kesimpulannya untuk mengukur tingkat kualitas dalam pelayanan yang telah diberikan KBIH At-Taqwa kepada calon jamaah haji dan umrah, KBIH AtTaqwa berusaha dengan semaksimal mungkin untuk untuk menerima kritik dan saran para calon jamaah haji dan umrah atas ketidak nyamanan ketika pra/sebelum dan pasca/setelah haji dan umrah. Selain itu, kelebihan pada KBIH At-Taqwa ini mengadakan Kafillah Alumni atau disebut dengan Ikatan Alumni Haji dan umrah (IAHU) untuk menjalankan selaturrahmi antara para jamaah haji dan umrah kepada para staff KBIH At-Taqwa sehingga terus terjaga komunikasi dengan baik, baik kepada para jamaah haji dan umrah maupun kepata KBIH At-Taqwa sehingga kepuasan juga tetap terjaga.

\section{PENUTUP}

Berdasarkan hasil analisis dan pembahasan terhadap strategi kelompok bimbingan ibadah haji $(\mathrm{KBIH})$ At-Taqwa dalam meningkatkan pelayanan terhadap calon jamaah haji, yaitu yang difokuskan pada perencanaan, pelaksanaan program dan evaluasi agar berjalan efektif. Yang meliputi bimbingan manasik, dan sampai pelaksanaan ibadah haji yaitu memberikan pelayanan dalam kenyamanan yang terbaik dan bijaksana. Sehingga pada setiap tahunnya mendapat peningkatan calon jamaah haji setiap tahunnya. 
Pelayanan yang diterapkan oleh KBIH At-Taaqwa ini menunjukan siap membantu kebutuhan para calon jamaah haji/umrah, dan memberikan pelayana yang teraik terhadap calon jamaah haji, kerna sesuai dengan apa yang menjadi Mottonya "bersama kami anda aman dan nyaman". Hal ini bukan hanya hasil dari wawancara dari para staff KBIH At-Taaqwa saja, akan tetapi dari hasil wawancara masyarakat sekitarnya terutama para calon jamaah haji/umrah dan jamaah haji/umrah yang menggunakan jasa KBIH At-Taaqwa mengatakan bahwa merasa sangat puas. Maka dapat disimpulan sebagai berikut : 1). perencanaan KBIH AtTaqwa dalam meningkatkan pelayanan terhadap calon jamaah haji terdapat beberapa perencanaan pelayanan, yaitu: a). pelayana ketika pendaftaran sampai mendapatkan tahun pemberangkatan. b). Pelayanan proses pelaksanaan ibadah haji dan umrah. c). Pelayanan pasca haji/kafilah (ikatan alumni). 2). Pelaksanaan program-program yang sudah ditetapkan oleh KBIH At-Taqwa sesuai kebutuhan dan dengan adanya program yang telah diberikan maka calon jamaah haji mudah melaksanakan ibadah haji terutama bagi yang pelaksanakan pertama kalinya. Adapun program yang diberikan KBIH At-Taqwa yaitu: manasik haji, fasilitas kebutuhan pelaksanaan ibadah haji. 3). hasil program dalam pelaksanaan program $\mathrm{KBIH}$ At-Taqwa terutama dalam pembimbing terhadap calon jamaah haji dan keluhan-keluahan dari KBIH At-Taqwa. Adanya program hasil maka KBIH AtTaqwa tersebut bisa memperbaiki kekurangan atau ketidak puasan para calon jamaah haji dan menjadi KBIH yang lebih baik lagi.

\section{DAFTAR PUSTAKA}

Tamami, E. 1980. The Concept of Corporate Strategi. Jakarta: Erlangga.

Nasaruddin, U.A. (2010). Buku Pintar Haji \& Umrah. Jakarta: Pustaka Warga Negara.

Indonesia, R.A.D. (1998). Ketentuan Umum Tentang Haji dan Umrah. Jakarta: Dirjen Bimas Islam dan Urusan Haji.

Indonesia, R.D.U. Nomer 13 Tahun (2008). Tentang Penyelenggaraan Ibadah Haji.

Saladin, J. (2003). Manajemen Strategi \& Kebijakan Perusahaan. Bandung: Linda Karya.

Saladin, J. (2010). Manajemen Pemasaran, Analisis, Perencanaan, Pelaksanaan, dan Pengendalian. Bandung: Linda Karya.

Saladin, J. (2011). Manajemen Strategi. Bandung: Agung Ilmu Griya.

Stoner, AF. J. (1996). Manajemen. Jakarta: Erlangga.

Azis, R. (2010). Dakwah dalam paradigma pemberdayaan masyarakat muslim. Academic Journa 